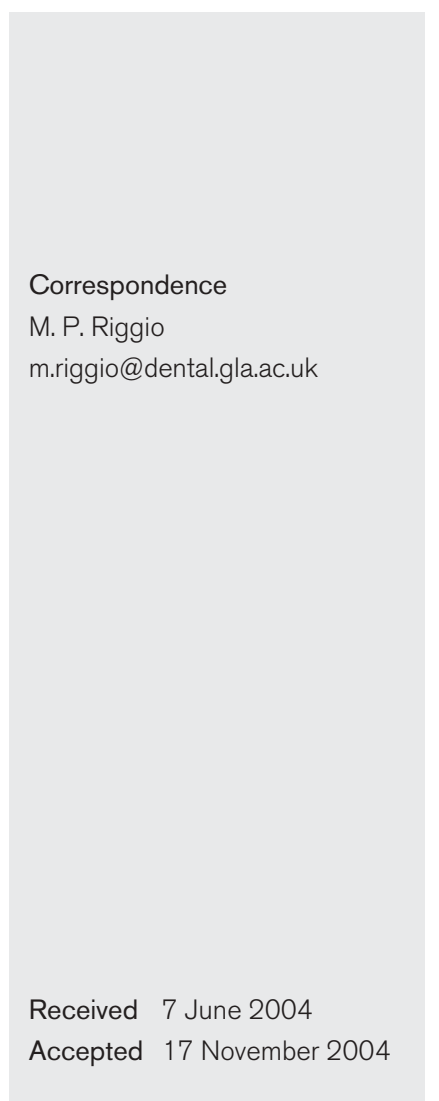

\section{A novel species-specific PCR assay for identifying Lactobacillus fermentum}

\author{
E. M. Dickson, M. P. Riggio and L. Macpherson \\ Infection and Immunity Research Section, University of Glasgow Dental School, 378 Sauchiehall \\ Street, Glasgow G2 3JZ, UK
}

\begin{abstract}
Lactobacillus fermentum is a Gram-positive bacterium that is associated with active caries lesions. Methods for identifying Lactobacillus species traditionally have been based upon culture methods coupled with biochemical tests, which are generally unreliable. The aim of this study was to develop a species-specific PCR assay for the direct detection of L. fermentum in oral clinical samples. PCR primers specific for $L$. fermentum were identified by alignment of bacterial $16 \mathrm{~S}$ rRNA genes and selection of sequences specific for $L$. fermentum at their $3^{\prime}$ ends. PCR positivity for $L$. fermentum DNA was indicated by amplification of a $337 \mathrm{bp}$ product. The primers were shown to be specific for L. fermentum DNA, since no PCR product was obtained when genomic DNA from a wide range of other oral bacteria, including closely related Lactobacillus species, were used as test species. The PCR assay was then used in an attempt to identify L. fermentum DNA in supragingival plaque samples and in pus aspirates from subjects with acute dento-alveolar abscesses. Four out of 70 $(5 \cdot 7 \%)$ supragingival plaque samples analysed were positive for the presence of $L$. fermentum DNA while none of the 19 pus samples analysed was positive for $L$. fermentum DNA. This PCR assay provides a more rapid, specific and sensitive alternative to conventional culture methods for the identification of L. fermentum in clinical specimens.
\end{abstract}

\section{INTRODUCTION}

Members of the genus Lactobacillus are Gram-positive organisms belonging to the general category of lactic acid bacteria. They are found in a wide variety of habitats, including vegetation and the gastrointestinal tracts of animals, and are used in the manufacture of fermented foods (Kandler \& Weiss, 1986). Lactobacillus species are also involved in the progression of carious lesions and have consistently been shown to be associated with caries in humans (Loesche \& Syed, 1973; van Houte, 1980; Botha et al., 1998). Lactobacillus fermentum is the major heterofermentative Lactobacillus species of the human gut (Fons et al., 1997), but it is also widely employed in industrial fermentation and as a starter culture in the dairy industry. Work carried out by Fitzgerald et al. (1981) demonstrated that strains of L. fermentum were cariogenic in conventional hamsters receiving high-sucrose diets. The organism has since been isolated frequently from active caries lesions (Botha et al., 1998).

The identification of Lactobacillus isolates by phenotypic methods is difficult because in some cases it requires determination of bacterial characteristics beyond those of popular fermentation tests (Kandler \& Weiss, 1986). Identification of L. fermentum involves the isolation of a Grampositive, non-spore-forming, catalase-negative, non-motile organism. Commercial kits, such as the API 50 CHL system, are also available to identify L. fermentum by analysis of enzymic and sugar-fermentation profiles. Since traditional methods can be time-consuming and often give rise to ambiguous results, more rapid and accurate identification methods are required. Sequence determination of Lactobacillus 16S rRNA genes provides an accurate basis for phylogenetic analysis and identification (Vandamme et al., 1996). The sequence obtained from an isolate can be compared with those of Lactobacillus species held in public access sequence databases. Although most of the species-specific sequences are contained in the first half of the 16S rRNA gene, identification is usually more accurate if the whole gene is sequenced (Tannock et al., 1999). Universal probes or primers that will anneal to the genes that code for rRNA of all eubacteria can be designed from conserved regions of the $16 \mathrm{~S}$ rRNA genes, and species-specific primers or oligonucleotide probes can be designed from highly variable regions of 16S rRNA genes (Drake et al., 1996).

There have been several reports of species-specific probes for different lactic acid bacteria derived from 16S and 23S rRNA gene sequences (Hensiek et al., 1992; Hertel et al., 1993; Ehrmann et al., 1994). However, there are no published works on the development of species-specific PCR primers for the detection of L. fermentum in clinical specimens. The objectives of this study were to identify species-specific PCR primers that allowed the direct detection of L. fermentum in clinical specimens, and to use the PCR assay in the attempted 
detection of $L$. fermentum in supragingival plaque samples from healthy subjects and in pus aspirates from subjects with acute dento-alveolar abscesses.

\section{METHODS}

Bacterial culture and genomic DNA purification. Lactobacillus reference strains were obtained from the National Centre for Type Cultures (NCTC) and ATCC. Bacteria were cultured on Rogosa SL agar (Becton Dickinson; Rogosa et al., 1951) and incubated at $37^{\circ} \mathrm{C}$ for $2-3$ days under anaerobic conditions in an atmosphere of $85 \% \mathrm{~N}_{2}, 10 \%$ $\mathrm{CO}_{2}$ and $5 \% \mathrm{H}_{2}$. Bacteria were harvested from the plates and genomic DNA extracted using the PureGene DNA Isolation kit (Novara Flowgen) according to the manufacturer's instructions.

Sample details. In total, 36 archival supragingival plaque samples from healthy subjects and 34 newly collected supragingival plaque samples from healthy subjects participating in a fluoridated milk study were analysed for the presence of $L$. fermentum. Nineteen archival pus samples that had previously been collected from patients with acute dento-alveolar abscesses were also analysed.

Sample collection and processing. Supragingival plaque samples were collected using a sterile curette into sterile tubes containing $1.0 \mathrm{ml}$ freshly prepared fastidious anaerobe broth (Bioconnections). Samples were vortex mixed for $30 \mathrm{~s}$ and $100 \mu \mathrm{l}$ aliquots lysed with $3 \mu \mathrm{l}$

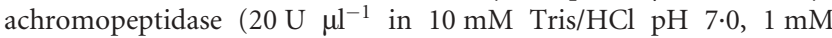
EDTA). Samples were incubated at $56{ }^{\circ} \mathrm{C}$ for $30 \mathrm{~min}$, boiled for $10 \mathrm{~min}$ and stored at $-70^{\circ} \mathrm{C}$ until required.

Aliquots (50 $\mu \mathrm{l}$ ) of each pus sample were diluted 10- to 100-fold in PCR diluent (10 mM Tris/HCl pH 8.0, $10 \mathrm{mM} \mathrm{NaCl}, 1 \mathrm{mM}$ EDTA). Thirty microlitres of $10 \%$ SDS and $3 \mu \mathrm{l}$ proteinase $\mathrm{K}\left(10 \mathrm{mg} \mathrm{ml}^{-1}\right)$ were then added to $300 \mu \mathrm{l}$ diluted pus and incubated at $55^{\circ} \mathrm{C}$ for $3 \mathrm{~h}$. Lysed samples were extracted twice with equal volumes of phenol/chloroform $(1: 1)$ and once with an equal volume of chloroform. DNA precipitation was performed by the addition of $0 \cdot 1 \mathrm{vol} .3 \mathrm{M}$ sodium acetate ( $\mathrm{pH} 5 \cdot 3$ ) and 2 vols $100 \%$ ethanol, followed by mixing and incubation at $-70{ }^{\circ} \mathrm{C}$ for $30 \mathrm{~min}$. Precipitated DNA was collected by centrifugation and the pellet resuspended in $100 \mu \mathrm{l}$ sterile, molecular biology-grade water.

PCR primers. The alignment of $16 \mathrm{~S}$ rRNA gene sequences of Lactobacillus species and other oral bacteria (Table 1) permitted the identification of primers specific for $L$. fermentum. Two primers were selected that showed sequence specificity for L. fermentum at their $3^{\prime}$ ends: 5'-AATACCGCATTACAACTTTG-3' (LF1; nt 196-215) and 5'GGTTAAATACCGTCAACGTA-3' (LF2; nt 529-510), which gave an expected amplification product of $337 \mathrm{bp}$.

PCR. All PCR reactions were performed in a total volume of $50 \mu \mathrm{l}$, comprising $5 \mu \mathrm{l}$ bacterial DNA template and $45 \mu \mathrm{l}$ reaction mixture containing $1 \times$ PCR buffer $(10 \mathrm{mM}$ Tris/ $\mathrm{HCl} \mathrm{pH} 9 \cdot 0,50 \mathrm{mM} \mathrm{KCl}$, $1.5 \mathrm{mM} \mathrm{MgCl} 2,0 \cdot 1 \%$ Triton X-100,), $1.0 \mathrm{U}$ Taq DNA polymerase (Promega), $0 \cdot 2 \mathrm{mM}$ dNTPs and each primer at a concentration of $0 \cdot 2 \mu \mathrm{M}$. The reaction was carried out in an OmniGene thermal cycler (Hybaid). After an initial denaturation step at $94{ }^{\circ} \mathrm{C}$ for $5 \mathrm{~min}, 35$ cycles of denaturation at $94{ }^{\circ} \mathrm{C}$ for $1 \mathrm{~min}$, annealing at $50^{\circ} \mathrm{C}$ for $1 \mathrm{~min}$ and extension at $72{ }^{\circ} \mathrm{C}$ for $1 \mathrm{~min}$ were carried out, followed by a final extension step at $72{ }^{\circ} \mathrm{C}$ for $10 \mathrm{~min}$.

PCR quality control. Stringent anti-contamination measures were employed when carrying out PCR, as described previously (Riggio et al., 2000). Positive and negative control reactions were included with each batch of samples analysed by PCR. A standard PCR reaction mixture containing $10 \mathrm{ng}$ L. fermentum genomic DNA instead of sample was used as a positive control and the negative control contained water
Table 1. Bacterial 16S rRNA gene sequences used to create a multiple alignment, from which $L$. fermentum-specific PCR primers were derived

\begin{tabular}{|c|c|c|}
\hline Bacterial species & Strain number & $\begin{array}{c}\text { GenBank } \\
\text { accession no. }\end{array}$ \\
\hline Lactobacillus acidophilus & ATCC 4356 & M58802 \\
\hline Lactobacillus casei & ATCC 334 & D86517 \\
\hline $\begin{array}{l}\text { Lactobacillus delbrueckii subsp. } \\
\text { bulgaricus }\end{array}$ & ATCC 11842 & AY050171 \\
\hline $\begin{array}{l}\text { Lactobacillus delbrueckii subsp. } \\
\text { lactis }\end{array}$ & DSM 20072 & M58823 \\
\hline Lactobacillus fermentum & ATCC 14931 & M58819 \\
\hline Lactobacillus fructivorans & DSM 20203 & M58818 \\
\hline Lactobacillus gasseri & DSM 20243 & M58820 \\
\hline Lactobacillus hilgardii & DSM 20176 & M58821 \\
\hline Lactobacillus mali & DSM 20444 & M58824 \\
\hline Lactobacillus mucosae & CCUG 43179 & AF126738 \\
\hline Lactobacillus murinus & DSM 20452 & M58826 \\
\hline Lactobacillus oris & NCDO 2160 & X61131 \\
\hline $\begin{array}{l}\text { Lactobacillus paracasei subsp. } \\
\text { paracasei }\end{array}$ & JCM 8130 & D79212 \\
\hline Lactobacillus pentosus & JCM 1558 & D79211 \\
\hline Lactobacillus plantarum & JCM 1149 & D79210 \\
\hline Lactobacillus pontis & LMG 14188 & AJ422033 \\
\hline Lactobacillus reuteri & DSM 20016 & L23507 \\
\hline Lactobacillus rhamnosus & LR3 & AY675253 \\
\hline Lactobacillus sakei & DSM 20017 & M58829 \\
\hline $\begin{array}{l}\text { Lactobacillus salivarius subsp. } \\
\text { salicinius }\end{array}$ & DSM 20554 & M59054 \\
\hline $\begin{array}{l}\text { Lactobacillus salivarius subsp. } \\
\text { salivarius }\end{array}$ & ATCC 11741 & AF089108 \\
\hline Lactobacillus sanfranciscensis & DSM 20451 & M58830 \\
\hline Lactobacillus sharpeae & DSM 20505 & M58831 \\
\hline Lactobacillus thermophilus & ATCC 8317 & M58832 \\
\hline Lactobacillus vaginalis & NCTC 12197 & X61136 \\
\hline Lactobacillus vermiforme & ATCC 13133 & M59295 \\
\hline Lactobacillus zeae & ATCC 15820 & D86516 \\
\hline Bacteroides forsythus & ATCC 43037 & AB035460 \\
\hline Helicobacter pylori & ATCC 43504 & U01330 \\
\hline Peptostreptococcus anaerobius & ATCC 27337 & D14150 \\
\hline Prevotella intermedia & ATCC 25611 & L16468 \\
\hline Prevotella nigrescens & ATCC 33563 & L16471 \\
\hline Streptococcus intermedius & NCTC 11324 & X58311 \\
\hline Streptococcus mitis & NCTC 12261 & D38482 \\
\hline
\end{tabular}

instead of sample. PCR products were electrophoresed on $2 \%$ agarose gels stained with ethidium bromide $\left(0.5 \mu \mathrm{g} \mathrm{ml}^{-1}\right)$ and visualized with an ImageMaster Video Documentation System (Amersham Pharmacia Biotech).

Bacterial strains used as PCR controls. The following Lactobacillus type strains were used as PCR controls when testing the specificity of the L. fermentum primers: L. fermentum ATCC $14931^{\mathrm{T}}$; Lactobacillus salivarius subsp. salivarius ATCC $11741^{\mathrm{T}}$; Lactobacillus delbrueckii subsp. bulgaricus NCTC $12712^{\mathrm{T}}$; Lactobacillus acidophilus NCTC 1723; Lactobacillus vaginalis NCTC $12197^{\mathrm{T}}$; Lactobacillus plantarum NCTC 1406; Lactobacillus casei ATCC $393^{\mathrm{T}}$; Lactobacillus rhamnosus 
NCTC $6375^{\mathrm{T}}$, NCTC 10302; Lactobacillus oris ATCC $49062^{\mathrm{T}}$; Lactobacillus pontis ATCC $51518^{\mathrm{T}}$; Lactobacillus reuteri ATCC $23272^{\mathrm{T}}$. Additionally, the following bacteria were also used as PCR controls: Helicobacter pylori ATCC $43504^{\mathrm{T}}$; Escherichia coli NCTC 10418; Prevotella intermedia ATCC $25611^{\mathrm{T}}$; Peptostreptococcus anaerobius ATCC $27337^{\mathrm{T}}$; Prevotella nigrescens ATCC 25261; Bacteroides forsythus ATCC $43037^{\mathrm{T}}$; Streptococcus mitis NCTC $12261^{\mathrm{T}}$; Candida albicans NCTC 3153; Streptococcus intermedius NCTC $11324^{\mathrm{T}}$.

\section{RESULTS}

\section{Sensitivity and specificity of the $L$. fermentum PCR assay}

Following 35 cycles of amplification, the lower limit of detection of the PCR assay was approximately 50 bacterial cells (data not shown).

The specificity of the L. fermentum PCR assay was confirmed by carrying out PCR using 10 ng genomic DNA from the 12 Lactobacillus strains and nine other oral bacteria selected as PCR controls. Only L. fermentum DNA produced a positive result with the LF1/LF2 primer pair (data not shown), thus confirming the specificity of the assay for L. fermentum.

\section{PCR analysis of clinical samples}

L. fermentum DNA was detected in four out of $70(5 \cdot 7 \%)$ of the supragingival plaque samples analysed. Some of these PCR-positive samples are shown in Fig. 1. Of these samples, 36 were archival samples from healthy subjects and 34 were from subjects participating in a fluoridated milk study. All four PCR-positive samples were from subjects participating in the fluoridated milk study. None of the 19 pus samples analysed by PCR contained L. fermentum DNA. Since there was a low incidence of $L$. fermentum in the clinical samples analysed, a random selection of five plaque and three pus samples were spiked with $10 \mathrm{ng}$ L. fermentum ATCC $14931^{\mathrm{T}}$ DNA in order to rule out the possibility of interference from PCR inhibitors within these samples. This confirmed that that there was no inhibition of the PCR assay, since L. fermentum was detected in all eight spiked samples (Fig. 2).

\section{PCR analysis of clinical isolates}

The L. fermentum PCR assay was also used to confirm the identity of 19 clinical isolates that had been previously been identified as L. fermentum using a 16S rRNA gene PCR-RFLP method (unpublished data) (Fig. 3). An additional four

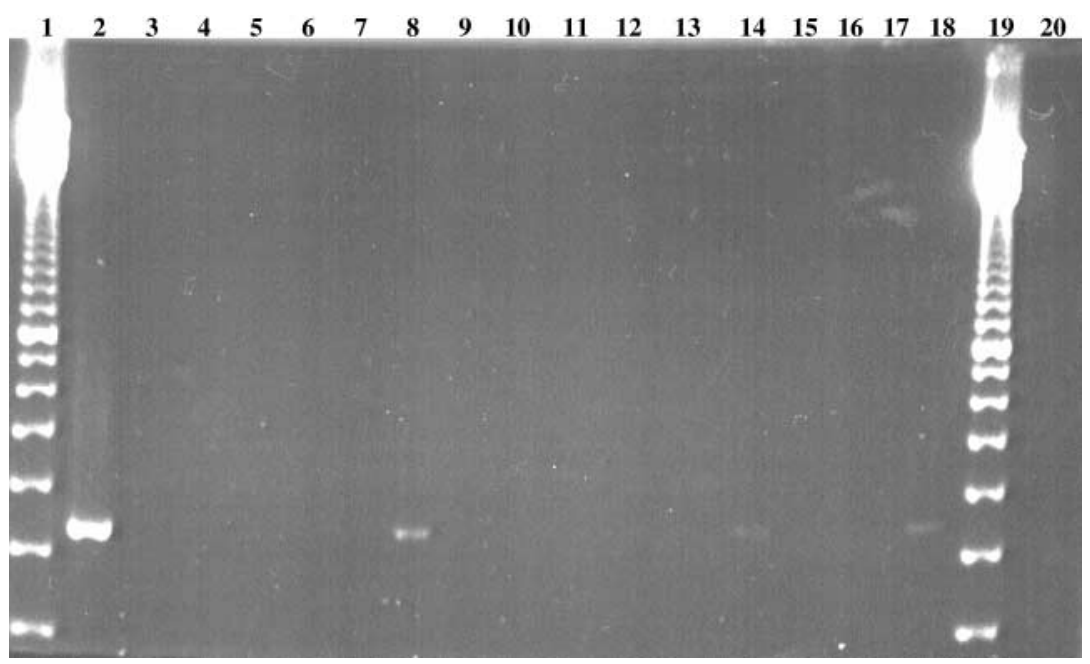

Fig. 1. Electrophoresis on a $2 \%$ agarose gel of selected PCR products obtained from supragingival plaque samples following PCR with primers specific for L. fermentum. Lanes 1 and 19, 100 bp DNA ladder; lane 2, positive control; lanes 3-18, supragingival plaque samples; lane 20, negative control.

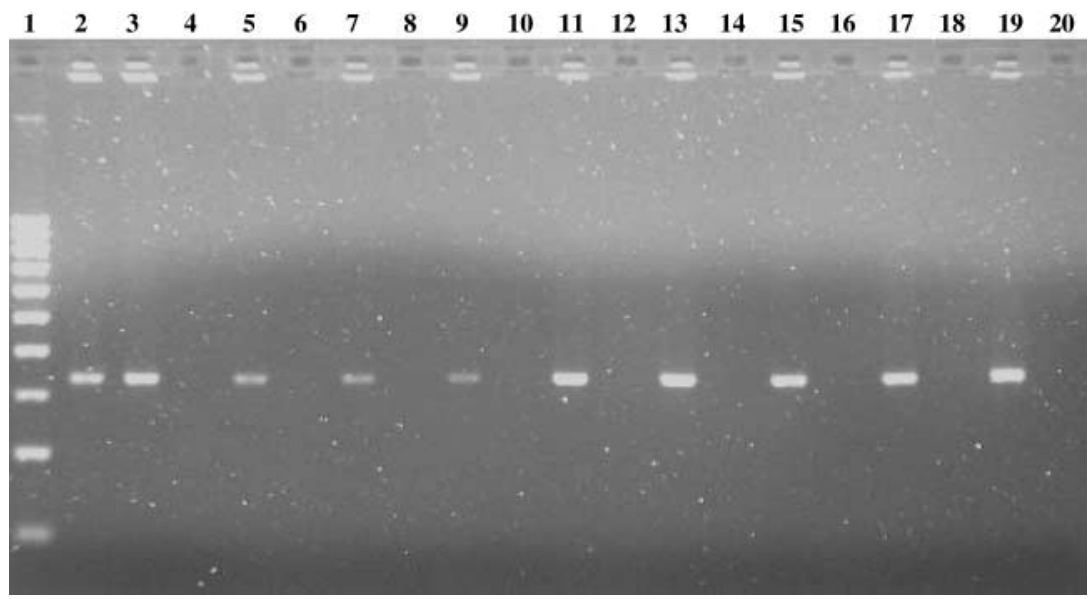

Fig. 2. Electrophoresis on a $2 \%$ agarose gel of PCR products obtained from a selection of plaque and pus samples spiked with $10 \mathrm{ng}$ of $L$. fermentum $(L f)$ DNA following $L$. fermentumspecific PCR. Lane 1, 100 bp DNA ladder; lanes 2 and 3, L. fermentum ATCC $14931^{\top}$; lane 4, plaque 1 ; lane 5 , plaque $1+L f$; lane 6 , plaque 2 ; lane 7 , plaque $2+L f$; lane 8 , plaque 3; lane 9, plaque $3+L f$; lane 10 , plaque 4 ; lane 11 , plaque $4+L f$; lane 12 , plaque 5 ; lane 13 , plaque $5+L f$; lane 14 , pus 1 ; lane 15 , pus $1+L f$; lane 16 , pus 2; lane 17, pus $2+L f$; lane 18, pus 3; lane 19, pus $3+L f$; lane 20 , negative control. 


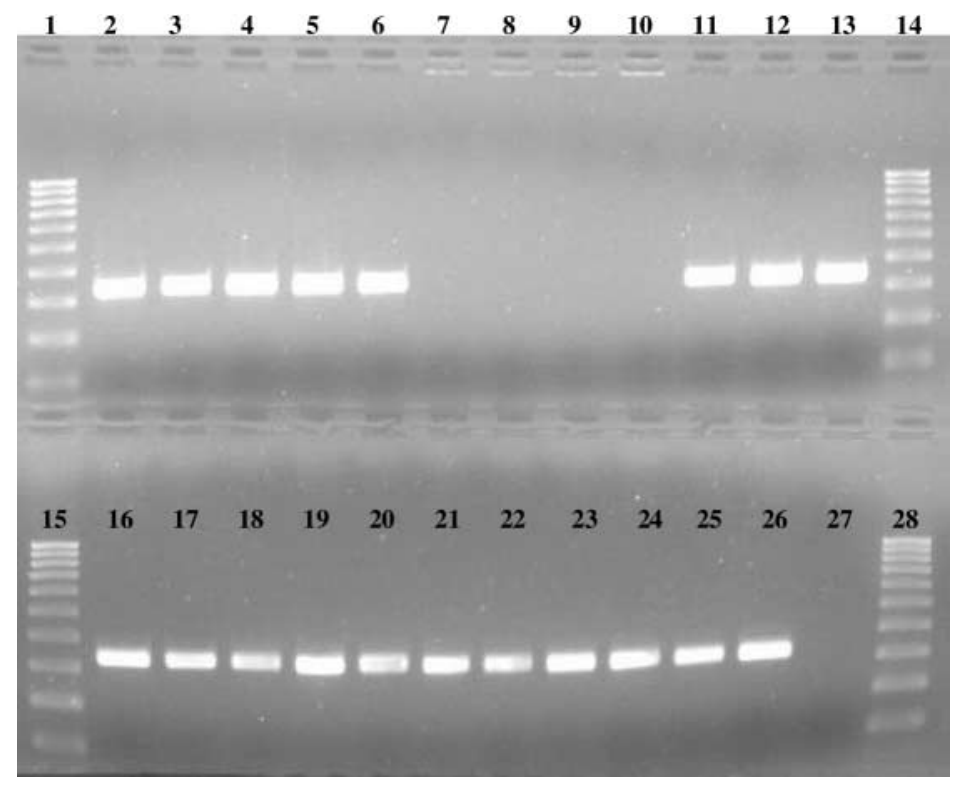

Fig. 3. Electrophoresis on a $2 \%$ agarose gel of PCR products obtained from 19 clinical isolates identified as $L$. fermentum using a $16 \mathrm{~S}$ rRNA gene PCR-RFLP method, and four unidentified isolates, following $L$. fermentum-specific PCR. Lanes 1, 14, 15 and 28, 100 bp DNA ladder; lanes 2-6, 11-13 and 16-26, L. fermentum clinical isolates; lanes $7-10$, unidentified isolates; lane 27, negative control.

Lactobacillus isolates of unknown identity did not give a positive PCR reaction and were therefore confirmed as species other than L. fermentum (Fig. 3).

\section{DISCUSSION}

The aims of this study were to develop a novel PCR assay that was specific for L. fermentum and apply this to the direct detection of $L$. fermentum DNA in clinical samples. The PCR assay was shown to be specific for $L$. fermentum since other bacterial species, including several species within the closely related Lactobacillus genus, were not detected with the PCR primers used. The PCR assay detected $L$. fermentum DNA in four supragingival plaque samples from patients participating in a fluoridated milk study, but not in pus aspirates from subjects with dento-alveolar abscesses. Previous 16S PCRRFLP analysis of Lactobacillus species in our laboratory identified a number of possible L. fermentum isolates and the use of this species-specific PCR assay was able to confirm the identification of 19 of the isolates as L. fermentum, but not a further four isolates that had very similar RFLP profiles.

The identification of L. fermentum and other members of this genus has previously been based on colony morphology, Gram-stain reaction, sugar-fermentation profiles and enzymic activities. The API 50 CHL system, which utilizes the characteristics of bacterial sugar fermentation and enzymic activities, has been used for the identification of L. fermentum. However, these conventional methods often lead to ambiguous results and even misidentifications. For example, Song et al. (1999) compared the results of API 50 CHL tests with DNA-DNA hybridization and showed that only $30 \cdot 2 \%$ of the Lactobacillus strains tested were correctly identified by the API 50 CHL tests.

Another problem with characterizing oral members of the Lactobacillus genus is that strains found in saliva are phenotypically close (Richard et al., 2001). Discrimination between L. rhamnosus and Lactobacillus plantarum has been recorded as difficult due to the small variation in phenotypic characters. Genotypic methods are becoming the most commonly used taxonomic tools for the characterization of lactobacilli, although very few have been developed to enable more accurate identification of oral lactobacilli. As L. fermentum has been frequently identified from active caries lesions, it was timely and useful for our present study to develop a rapid and reliable method that could be used for the identification of this species in various oral clinical specimens.

Other molecular techniques have been applied in an attempt to identify L. fermentum, mainly from food products. Vogel et al. (1994) utilized whole-cell protein patterns and 16S rRNA gene patterns to demonstrate the different phylogenic locations of L. fermentum and L. plantarum. Ribotyping (Rodtong \& Tannock, 1993; McCartney et al., 1996; Zhong et al., 1998), PFGE (McCartney et al., 1996) and random amplified polymorphic DNA analysis (Veyrat et al., 1999; Nigatu, 2000) have all been applied to the identification of L. fermentum. Species-specific oligonucleotide probes have been used for the successful identification of other important Lactobacillus species (Nakagawa et al., 1994; Drake et al., 1996; Tilsala-Timisjärvi \& Alatossava, 1997; Yasui et al., 1997; Lucchini et al., 1998; Alander et al., 1999; Chagnaud et al., 2001). However, there are no studies that report the use of specific oligonucleotide primers with direct PCR for identifying $L$. fermentum and their application to clinical samples. Song et al. (2000) reported the use of a two-step multiplex PCR assay for identifying isolates of 11 human intestinal lactobacilli, including L. fermentum. Although the method identified nine L. fermentum isolates among a bank of 84 isolates obtained from human stools, the method was not applied to direct detection of $L$. fermentum in clinical samples, where a mixed microflora is invariably present, as we have done in our current study. 
In conclusion, this study reports the use of a novel, speciesspecific PCR assay that can directly detect $L$. fermentum in clinical samples and which can also be used to confirm the identification of isolates obtained from microbiological culture of clinical samples. The application of this assay could be useful in studies investigating the incidence of L. fermentum within the oral cavity, especially within saliva, and its influence on the caries process.

\section{ACKNOWLEDGEMENTS}

We would like to thank the Borrow Dental Milk Foundation for their generous financial support.

\section{REFERENCES}

Alander, M., Satokari, R., Korpela, R., Saxelin, M., Vilpponen-Salmela, T., Mattila-Sandholm, T. \& von Wright, A. (1999). Persistence of colonization of human colonic mucosa by a probiotic strain, Lactobacillus rhamnosus GG, after oral consumption. Appl Environ Microbiol 65, 351-354.

Botha, S. J., Boy, S. C., Botha, F. S. \& Senekal, R. (1998). Lactobacillus species associated with active caries lesions. J Dent Assoc Sth Afr 53, 3-6.

Chagnaud, P., Machinis, K., Coutte, L. A., Marecat, A. \& Mercenier, A. (2001). Rapid PCR-based procedure to identify lactic acid bacteria: application to six common Lactobacillus species. J Microbiol Methods 44, 139-148.

Drake, M., Small, C. L., Spence, K. D. \& Swanson, B. G. (1996). Rapid detection and identification of Lactobacillus spp. in dairy products by using the polymerase chain reaction. J Food Prot 59, 1031-1036.

Ehrmann, M., Ludwig, W. \& Schleifer, K. H. (1994). Reverse dot blot hybridization: a useful method for the direct identification of lactic acid bacteria in fermented food. FEMS Microbiol Lett 117, 143-149.

Fitzgerald, R. J., Adams, B. O., Fitzgerald, D. B. \& Knox, K. W. (1981). Cariogenicity of human plaque lactobacilli in gnotobiotic rats. J Dent Res 60, 919-926.

Fons, M., Hégé, T., Ladiré, M., Raibaud, P., Ducluzeau, R. \& Maguin, E. (1997). Isolation and characterization of a plasmid from Lactobacillus fermentum conferring erythromycin resistance. Plasmid 37, 199-203.

Hensiek, R., Krupp, G. \& Stackebrandt, E. (1992). Development of diagnostic oligonucleotide probes for 4 Lactobacillus species occurring in the intestinal tract. Syst Appl Microbiol 15, 123-128.

Hertel, C., Ludwig, W., Pot, B., Kersters, K. \& Schleifer, K. H. (1993). Differentiation of lactobacilli occurring in fermented milk products by using oligonucleotide probes and electrophoretic protein profiles. Syst Appl Microbiol 16, 463-467.

Kandler, O. \& Weiss, N. (1986). Genus Lactobacillus. In Bergey's Manual of Systematic Bacteriology, vol. 2, pp. 1209-1234. Edited by P. H. A. Sneath, N. S. Mair, M. E. Sharpe \& J. G. Holt. Baltimore: Williams \& Wilkins.

Loesche, W. J. \& Syed, S. A. (1973). The predominant cultivable flora of carious plaque and carious dentine. Caries Res 7, 201-216.

Lucchini, F., Kmet, V., Cesena, C., Coppi, L., Bottazzi, V. \& Morelli, L. (1998). Specific detection of a probiotic Lactobacillus strain in faecal samples by using multiplex PCR. FEMS Microbiol Lett 158, 273-278.
McCartney, A. L., Wenzhi, W. \& Tannock, G. W. (1996). Molecular analysis of the composition of the bifidobacterial and lactobacillus microflora of humans. Appl Environ Microbiol 62, 4608-4613.

Nakagawa, T., Shimada, M., Mukai, H., Asada, K., Kato, I., Fujino, K. \& Sato, T. (1994). Detection of alcohol-tolerant hiochi bacteria by PCR. Appl Environ Microbiol 60, 637-640.

Nigatu, A. (2000). Evaluation of numerical analyses of RAPD and API 50 $\mathrm{CH}$ patterns to differentiate Lactobacillus plantarum, Lact. fermentum, Lact. rhamnosus, Lact. sake, Lact. parabuchneri, Lact. gallinarum, Lact. casei, Weissella minor and related taxa isolated from kocho and tef. J Appl Microbiol 89, 969-978.

Richard, B., Groisillier, A., Badet, C., Dorignac, G. \& Lonvaud-Funel, A. (2001). Identification of salivary Lactobacillus rhamnosus species by DNA profiling and a specific probe. Res Microbiol 152, 157-165.

Riggio, M. P., Lennon, A. \& Wray, D. (2000). Detection of Helicobacter pylori DNA in recurrent aphthous stomatitis tissue by PCR. J Oral Pathol Med 29, 507-513.

Rodtong, S. \& Tannock, G. W. (1993). Differentiation of Lactobacillus strains by ribotyping. Appl Environ Microbiol 59, 3480-3484.

Rogosa, M., Mitchell, J. A. \& Wiseman, R. F. (1951). A selective medium for the isolation and enumeration of oral lactobacilli. J Dent Res 30, $682-689$.

Song, Y.-L., Kato, N., Matsumiya, Y., Liu, C.-X., Kato, H. \& Watanabe, K. (1999). Identification of Lactobacillus species of human origin by a commercial kit, API 50CHL. J Rapid Methods Autom Microbiol 10, 77-82.

Song, Y.-L., Kato, N., Liu, C.-X., Matsumiya, Y., Kato, H. \& Watanabe, K. (2000). Rapid identification of 11 human intestinal Lactobacillus species by multiplex PCR assays using group- and species-specific primers derived from the 16S-23S rRNA intergenic spacer region and its flanking 23S rRNA. FEMS Microbiol Lett 187, 167-173.

Tannock, G. W., Tilsala-Timisjärvi, A., Rodtong, S., Ng, J., Munro, K. \& Alatossava, T. (1999). Identification of Lactobacillus isolates from the gastrointestinal tract, silage, and yoghurt by $16 \mathrm{~S}-23 \mathrm{~S}$ rRNA gene intergenic spacer region sequence comparisons. Appl Environ Microbiol 65, 4264-4267.

Tilsala-Timisjärvi, A. \& Alatossava, T. (1997). Development of oligonucleotide primers from the $16 \mathrm{~S}-23 \mathrm{~S}$ rRNA intergenic sequences for identifying different dairy and probiotic lactic acid bacteria by PCR. Int $J$ Food Microbiol 35, 49-56.

Vandamme, P., Pot, B., Gillis, M., De Vos, P., Kersters, K. \& Swings, J. (1996). Polyphasic taxonomy, a consensus approach to bacterial systematics. Microbiol Rev 60, 407-438.

Van Houte, J. (1980). Bacterial specificity in the etiology of dental caries. Int Dent J 30, 305-326.

Veyrat, A., Miralles, M. C. \& Pérez-Martínez, G. (1999). A fast method for monitoring the colonization rate of lactobacilli in a meat model system. J Appl Microbiol 87, 49-61.

Vogel, R. F., Bocker, G., Stolz, P. \& 7 other authors (1994). Identification of lactobacilli from sourdough and description of Lactobacillus pontis sp. nov. Int J Syst Bacteriol 44, 223-229.

Yasui, T., Okamoto, T. \& Taguchi, H. (1997). A specific oligonucleotide primer for the rapid detection of Lactobacillus lindneri by polymerase chain reaction. Can J Microbiol 43, 157-163.

Zhong, W., Millsap, K., Bialkowska-Hobrzanska, H. \& Reid, G. (1998). Differentiation of Lactobacillus species by molecular typing. Appl Environ Microbiol 64, 2418-2423. 